\title{
THE ROLE OF NIOBIUM IN WROUGHT PRECIPITATION-HARDENED NICKEL-BASE ALLOYS
}

\author{
G. D. Smith and S. J. Patel \\ Special Metals Corporation \\ 3200 Riverside Drive \\ Huntington, WV 25705
}

Keywords: Niobium, microstructure, phases, alloy X-750, alloy 740, alloy 706, alloy 725, alloy 718

\begin{abstract}
Niobium is recognized as an important alloying element in a number of wrought precipitation-hardened nickel-base alloys. It is the purpose of this paper to examine the role that niobium plays in these alloys and describe the properties that are achieved as a result of its inclusion in wrought superalloys. In addition to the general alloying characteristics of niobium as described in the technical literature, the specific contribution of niobium in the alloys X-750, 740, 706, 725 and 718 will be examined. Niobium is examined for the role it plays microstructurally and the impact of the resulting microstructure on certain properties.
\end{abstract}

\section{Introduction}

Alloys X-750, 740, 706, and 718 fit the definition of a superalloy in that they are alloys developed for elevated temperature service, where severe mechanical stress is encountered and high surface integrity is usually required. These four superalloys are commonly considered to be nickel-base alloys although alloys 706 and 718 contain significant levels of iron to reduce the cost of these alloys intended for such applications as large forgings. It seems appropriate to begin by examining the relevant properties of the element, niobium, as it pertains to its use in superalloys. In our alloys of interest, niobium is present in small-to-moderate amounts and contributes in a significant way to alloy properties. As alloys generally intended for gas turbine service, these alloys must meet stringent criteria for tensile strength and ductility, rupture and creep strength with inherent stability and ductility, favorable low-cycle fatigue requirements and even requirements on density, thermal conductivity and expansion characteristics.

Alloy 725 , while not primarily a high temperature aerospace alloy, is age hardenable to exceptionally high strength and known for its excellent resistance to marine and oil patch corrosion. Niobium in this alloy contributes not only to its strength but provides a high degree of resistance to pitting and crevice corrosion as well. This paper will seek to define the role that niobium plays in making these alloys premier materials of choice for today's aerospace, landbased gas turbine and oil country applications.

\section{The Elemental Properties of Niobium}

Niobium, a body-centered cubic (BCC) Group VA element, is one of the four major refractory elements used in superalloys along with molybdenum, tungsten and tantalum. These 
alloying elements, added singularly or in combination, contribute to solid solution strengthening, strengthening through carbide formation and in the case of niobium and tantalum to precipitation hardening as well. Niobium, as a refractory element, is of lower modulus, melting point and density than the other refractory elements. See Table I. Since effective solid solution hardening is suggested by high modulus and high melting point, it is clear that niobium is not as effective in solid solution hardening as the other refractory elements.

Table I. Selected Physical Properties of the Refractory Elements, Niobium, Molybdenum, $\underline{\text { Tantalum and Tungsten }}$

\begin{tabular}{|c|c|c|c|c|}
\hline & $\mathrm{Nb}$ & Mo & Ta & W \\
\hline Melting Point, ${ }^{\circ} \mathrm{C}$ & 2468 & 2610 & 2996 & 3410 \\
\hline Density, g/cm & & 10.2 & 16.6 & 19.3 \\
\hline Modulus, $\mathrm{n} / \mathrm{m}^{2} \times 10^{6}$ & 100 & 345 & 185 & 345 \\
\hline Atomic Radii, å & 2.852 & 2.720 & 2.854 & 2.735 \\
\hline
\end{tabular}

Atomic size as presented in Table I can contribute to solid solution strengthening as it influences relative solubility and impedes dislocation motion. Table II shows niobium to be the least soluble refractory element in nickel and nickel-20\% chromium. The atomic mismatch of niobium with nickel and iron is the greatest of the refractory elements. Mismatch certainly contributes to limiting solubility. This is also shown in Table II.

$\underline{\text { Table II. Factors Influencing Solid Solution Strengthening by the Refractory Elements in Nickel }}$ and Nickel-20\% Chromium Matrices.

\begin{tabular}{|c|c|c|c|c|}
\hline Solubility Limit & \multicolumn{4}{|c|}{ Solute Element (weight \%) } \\
\cline { 2 - 5 } $\begin{array}{c}\text { At } 1000-1200^{\circ} \mathrm{C} \\
\mathrm{Wt} \%\end{array}$ & $\mathrm{Nb}$ & $\mathrm{Mo}$ & $\mathrm{Ta}$ & $\mathrm{W}$ \\
\hline $\mathrm{Ni}$ & 10 & 26 & 12 & 17 \\
\hline $\mathrm{Ni}-20 \% \mathrm{Cr}$ & 7 & 23 & 12 & 33 \\
\hline
\end{tabular}

\begin{tabular}{|c|c|c|c|c|}
\hline \multirow{2}{*}{$\begin{array}{c}\text { Atom Size } \\
\text { Mismatch } \\
\text { Wt \% vs. }\end{array}$} & $\mathrm{Nb}$ & Mo & Ta & W \\
\cline { 2 - 5 } & 10.8 & 5.7 & 10.6 & 6.3 \\
\hline $\mathrm{Fe}$ & 14.7 & 9.4 & 14.4 & 10.0 \\
\hline $\mathrm{Ni}$ & &
\end{tabular}

Niobium is the most electropositive of the four refractory elements. This electropositive characteristic defines why niobium has a strong affinity for the formation of $\mathrm{A}_{3} \mathrm{~B}$-type TCP phases. Niobium substitutes for aluminum in $\gamma^{\prime}\left(\mathrm{Ni}_{3} \mathrm{Al}\right)$ as does titanium. Niobium also forms $\gamma^{\prime \prime}\left(\mathrm{Ni}_{3} \mathrm{Nb}\right)$, the body-centered tetragonal (BCT) strengthener phase, in alloys 706 and 718. The electropositive nature of niobium favors $\mathrm{NbC}(-\Delta \mathrm{F}=30 \mathrm{Kcal} / \mathrm{g}$-atom $)$ and $\mathrm{NbN}(-\Delta \mathrm{F}=38$ $\mathrm{Kcal} / \mathrm{g}$-atom), usually present to some extent as primary or secondary phases in our alloys of this study. Carbon and nitrogen can combine to form primary and secondary $\mathrm{Nb}(\mathrm{C}, \mathrm{N})$ as well. Niobium has a moderate affinity for oxygen forming $\mathrm{Nb}_{2} \mathrm{O}_{5}\left[1 / 5 \mathrm{Nb}_{2} \mathrm{O}_{5}(-\Delta \mathrm{F}=38 \mathrm{Kcal} / \mathrm{g}\right.$-atom $\left.)\right]$.

Since niobium has the potential to strengthen a nickel-base alloy by solid solution strengthening, carbide formation and by coherent precipitation hardening phase formation. Let us look at each of these strengthening mechanisms in turn with niobium in mind. 


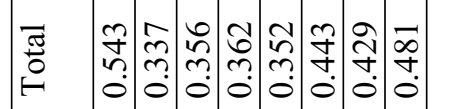

- ㅇำ

$\sum^{\circ}$

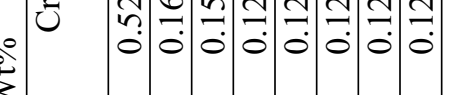

节

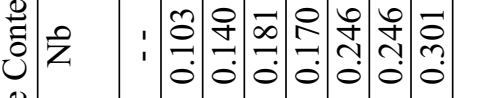

过

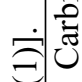

호ำ

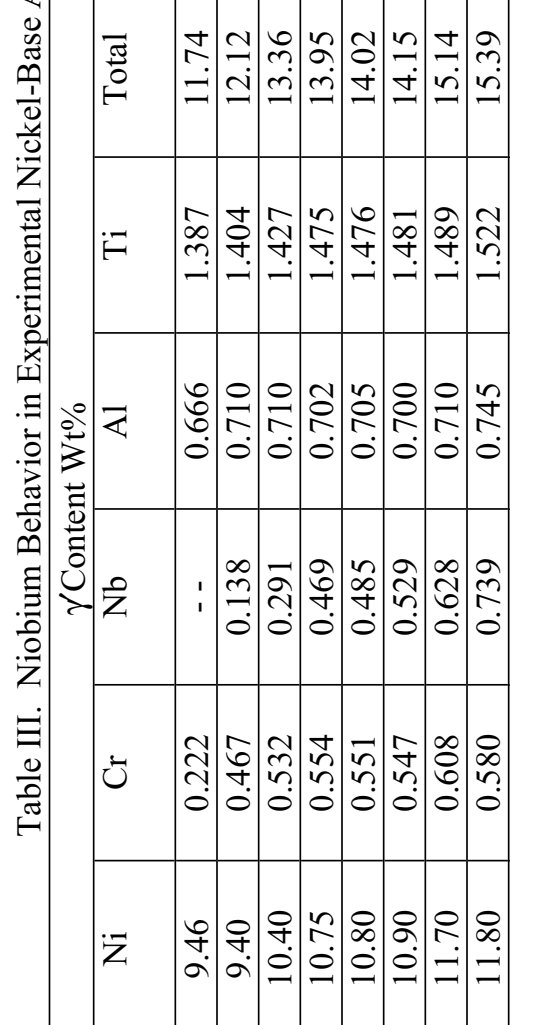

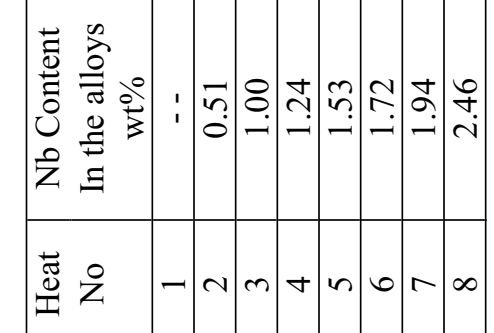

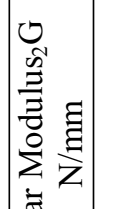

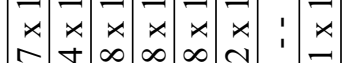

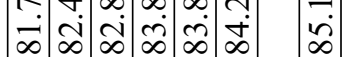

$\frac{\pi}{\sqrt{2}}$

.0:

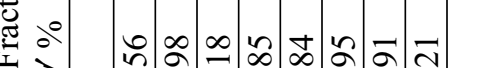

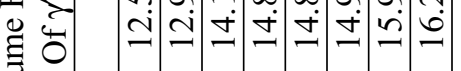

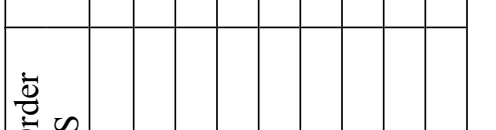

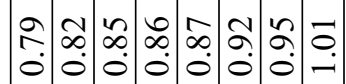

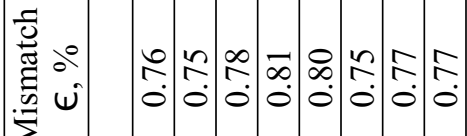

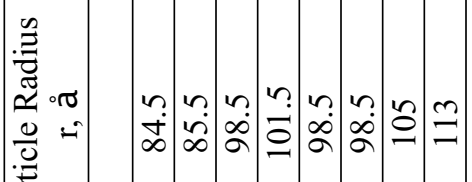
है
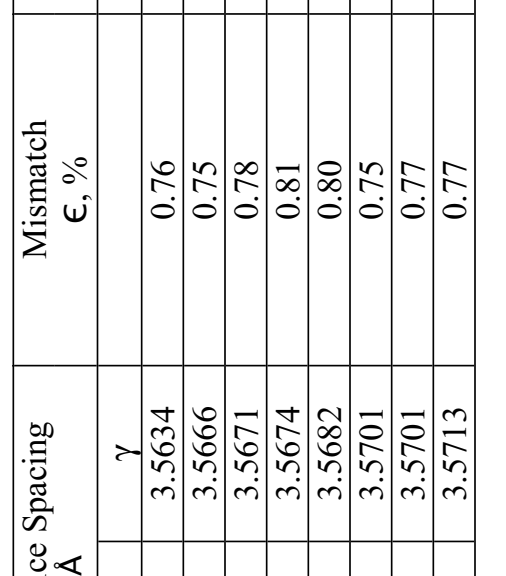

正

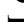

$300=0000$

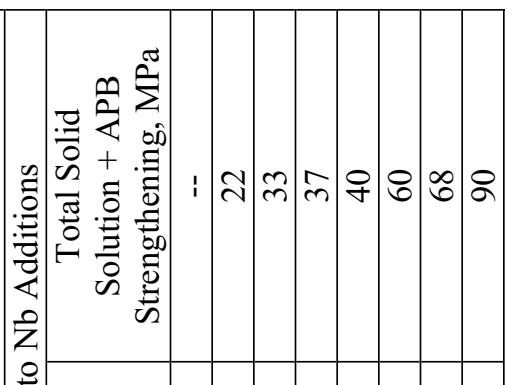

疍

एँ

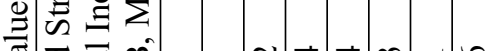

$>$ 믈

$\infty \geqslant$

还完

กั้

$\cdot \cdot \cdot \frac{0}{\square}$

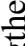

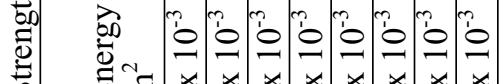

空

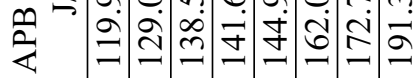

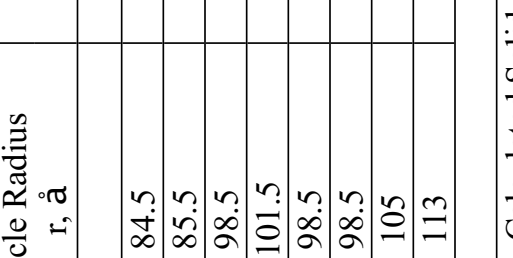

욤

$\because$

总

三

Uึ่

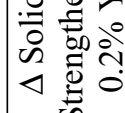

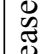

$\dot{\vec{c}}$

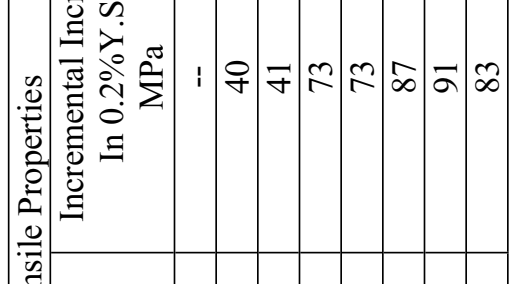

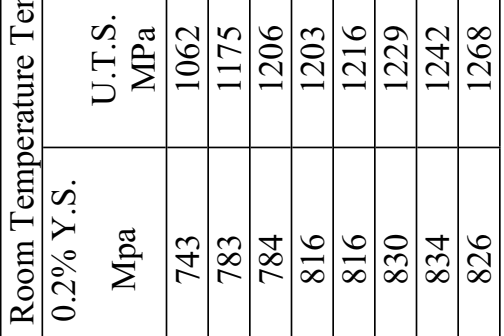

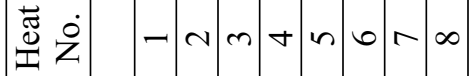




\section{Solid Solution Strengthening with Niobium in Nickel-Base Alloys}

Foreign atom substitution in a lattice can cause strain by lattice expansion which in turn interacts with dislocations. As presented in Table I, niobium does not dissolve extensively in nickel or nickel-20\% chromium alloys. It is limited to about $7 \%$ in nickel-20\% chromium at $1200^{\circ} \mathrm{C}$ and becomes less with decreasing temperature. Atomic size mismatch at about $15 \%$ with respect to nickel is too large to allow greater solubility. However, this size mismatch does imply a potential for a measurable effect per niobium atom in creating lattice strain. An early study of the effect of niobium in nickel-20\% chromium is of immense value in understanding the solid solution effects of niobium in the alloys of this paper.

Guo and Ma studied the behavior of niobium in a nickel-20\% chromium matrix slightly strengthened with $\gamma$ and carbon (1). These investigators vacuum melted this matrix base with eight levels of niobium from $0 \%$ to $2.4 \%$. Following fabrication of bar, the compositions were solution heat treated at $1080^{\circ} \mathrm{C} / 8 \mathrm{~h} / \mathrm{AC}$ and subsequently aged at $750^{\circ} \mathrm{C} / 16 \mathrm{~h} / \mathrm{AC}$. The authors then proceeded to separate the phases and analyze them for alloy content and lattice spacing, measure particle sizes, determine volume fraction of $\gamma^{\prime}$, mismatch and the long range order parameter, S. Room Temperature tensile data were also obtained and the yield strength increase for the incremental additions of niobium were determined and assessed for their contribution to strengthening. Table III summarizes their results.

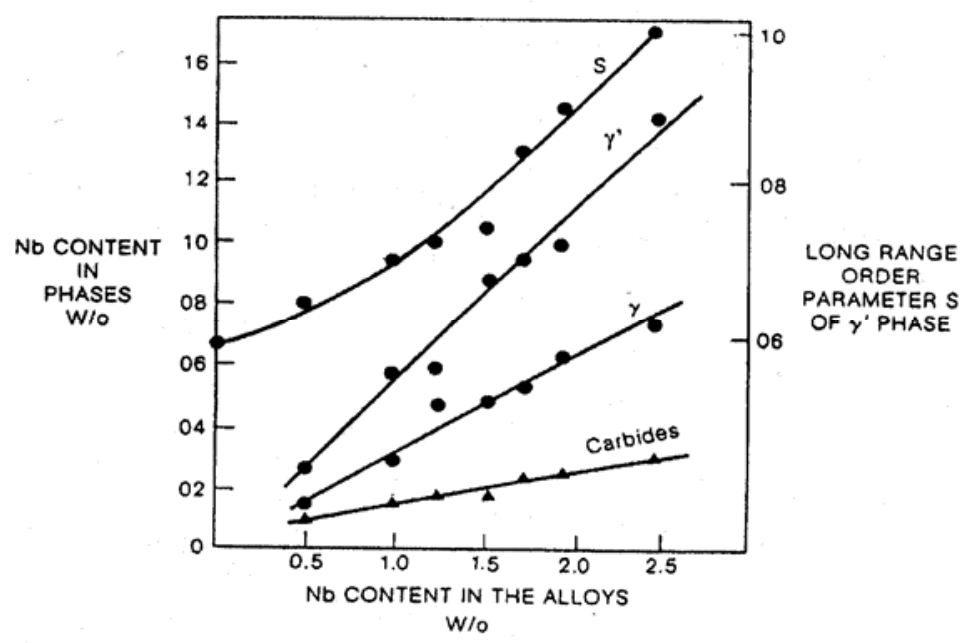

Figure 1: Partitioning of Niobium to $\gamma, \gamma^{\prime}$ and the Carbides along with the Long-Range Order Parameter "S" of $\gamma$ ' in Solid Solution Nickel-Base Alloys Containing 0 to 2.5\% Niobium (1).

Figure 1 depicts the partitioning of niobium to the various phases found, i.e., $\gamma, \gamma$ and the carbides. At any given niobium content, the bulk of the niobium partitions to the $\gamma(\sim 57 \%)$ followed by partitioning to $\gamma(\sim 28 \%)$ and least to the carbides $(\sim 15 \%)$. These authors found niobium increased the lattice spacing of $\gamma$ slightly from $3.5634 \mathrm{~nm}$ at $0 \%$ niobium to $3.5713 \mathrm{~nm}$ at $2.46 \%$ niobium. Lattice mismatch of $\gamma$ to $\gamma$ increased from 0.76 in the niobium-free composition to 0.81 at $1.24 \%$ niobium and then decreased to the original mismatch value at $2.46 \%$ niobium. The shear modulus increased from $81.7 \times 10^{3}$ to $85.0 \times 10^{3}$ over the range of niobium content studied. Guo and $\mathrm{Ma}$ have confirmed a solid solution strengthening effect for niobium that is germane to alloys X-750, 740, 706, 725 and 718 containing $20 \%$ chromium in their nickel and nickel-iron matrices. Their estimate is that the yield strength had been increased by $\sim 44 \mathrm{MPa}$ due to solid solution strengthening by the addition of $2.46 \%$ niobium. This is roughly one half of the total room temperature yield strength increase attributed to the addition 
of the niobium. Because the mismatch between the $\gamma$ and $\gamma^{\prime}$ phases did not significantly change with increasing niobium content, it was concluded that niobium's contribution to coherency strain due to mismatch is small. See Table III. Hence the addition of niobium does not raise strength through increasing coherency strain via mismatch. The balance of the strength increase in their alloys was attributed principally to coherency strain strengthening through the role of niobium in increasing APB (antiphase boundary) energy of the alloys.

\section{Carbide Strengthening by Niobium in Nickel-Base Alloys}

Carbides, in general, are particularly useful in aiding structural refinement during fabrication and heat treatment by assisting in grain size control. They strengthen the matrix when present intragranularly and aid high temperature strength by inhibiting slip in grain boundaries. Conversely, carbides can also be a source at which dislocations are generated and fatigue cracks are initiated. Among the carbides, niobium usually forms a MC type carbide in the as-cast and hot worked conditions. During subsequent thermal exposure, the MC type carbide might be expected to degenerate into a chromium-containing $\mathrm{M}_{23} \mathrm{C}_{6}$ type carbide by way of the following reaction:

$$
\mathrm{MC}+\gamma=\mathrm{M}_{23} \mathrm{C}_{6}+\gamma^{\prime}
$$

This reaction has been documented by Mihalisin in a $2 \%$ niobium-containing cast alloy 713C (2). Niobium is believed to retard the reaction rate of $\mathrm{MC}$ type carbides to $\mathrm{M}_{23} \mathrm{C}_{6}$ type carbides. Beattie speculates that the stability of the $\mathrm{MC}$ type carbides decreases in the following order $-\mathrm{TaC}>\mathrm{NbC}>\mathrm{TiC}>\mathrm{VC}$ (3). Sims reports that niobium is about equal to tantalum in stabilizing MC type carbides (4). Molybdenum is believed to destabilize $\mathrm{NbC}$ (5). Guo and Ma reported in their study that $\sim 15 \%$ of the niobium content partitioned to the carbide phase, assumed to be MC type carbides.

\section{Coherent Phase Strengthening by Niobium in Nickel-Base Alloys}

The most significant strengthening mechanism in nickel-base alloys is precipitation strengthening from $\gamma^{\prime}\left(\mathrm{Ni}_{3} \mathrm{Al}\right)$. This phase causes strengthening through generation of coherency strains with the matrix lattice via its effect on APB energy in dislocation cutting, strength and size of the $\gamma$ and other factors. Gamma prime allows substitution by niobium and titanium for aluminum and substitution of chromium and cobalt for nickel.

Mihalisin found niobium substituted for about $10 \%$ of the aluminum in cast alloy $713 \mathrm{C}$ (2). Kriege and Baris in analyzing a series of superalloys found niobium to substitute for about $12 \%$ of the aluminum in $\gamma(6)$. Adding niobium to a $\gamma^{\prime}$-containing alloy can increase the amount of $\gamma^{\prime}$ and change its stability as well. Importantly, Thornton et al. found that niobium as well as titanium doubled the flow strength of $\gamma$ at typical superalloy service temperature, i.e., $600^{\circ} \mathrm{C}$ to $900^{\circ} \mathrm{C}(7)$. See Figure 2.

The study of Guo and Ma is especially relevant with respect to $\gamma^{\prime}$ strengthening (1). These investigators found that niobium partitioned to the $\gamma^{\prime}$ in approximately 1:2 to that found in the matrix as shown in Figure 1. As the niobium content increased from $0 \%$ to $2.46 \%$, the 


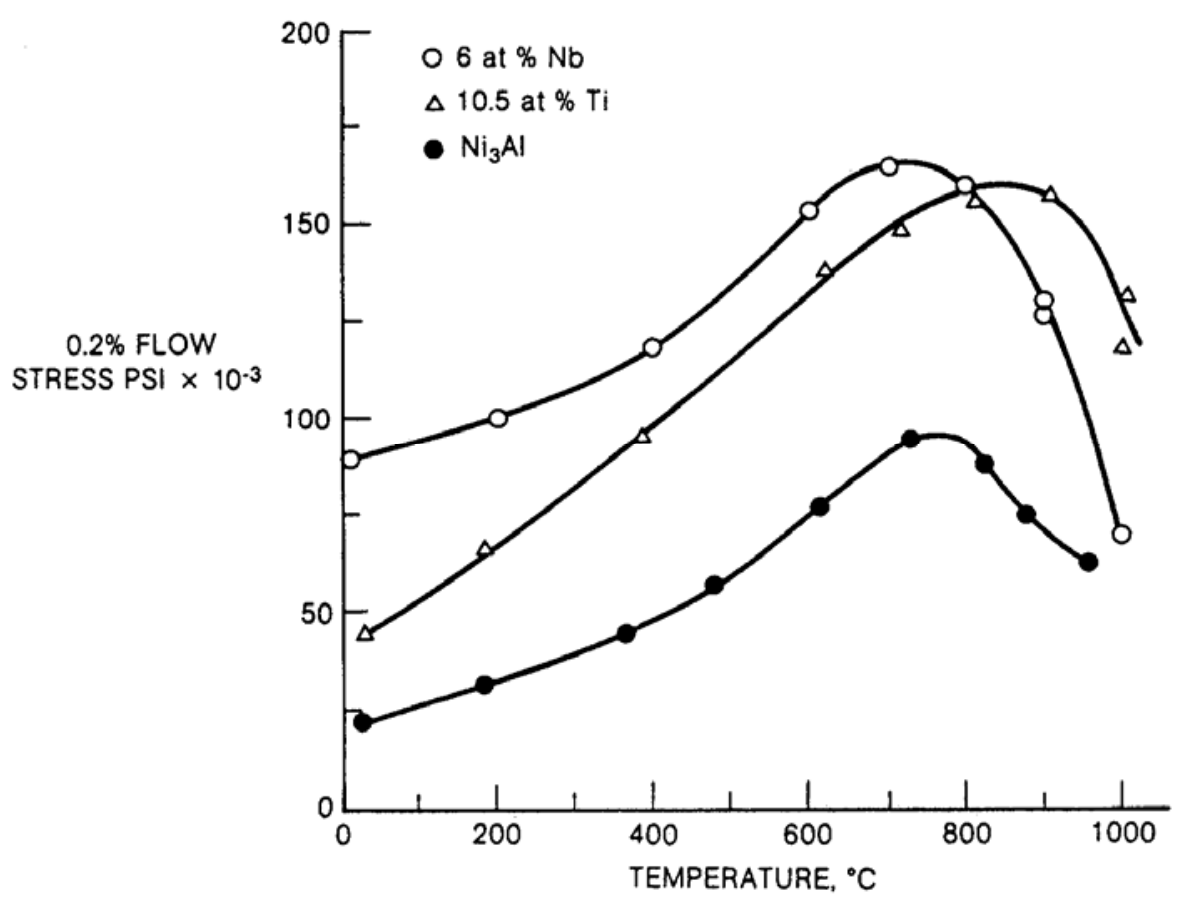

Figure 2: Effect of Alloying with Niobium and Titanium on the Flow Stress of $\gamma^{\prime}(8)$.

amount of $\gamma^{\prime}$ increased $30 \%$ from $12.56 \%$ to $16.21 \%$, while lattice mismatch initially increased from 0.76 to 0.81 at $1.24 \%$ niobium and back to 0.77 at $2.46 \%$ niobium. Niobium increases the amount of $\gamma$ both by contributing to its formation and also by decreasing the solubility of aluminum and titanium in the matrix, which in turn can further increase the amount of $\gamma^{\prime}$. Guo and $\mathrm{Ma}$ in their study found that lattice mismatch caused by niobium contributed little to coherency strain and hence to yield strength increase. Utilizing the values of long-range order that increased with increasing niobium content, they calculated that the APB energy had increased $60 \%$ over that of the niobium-free composition. See Table III. They thus attributed about half the increase in yield strength associated with increasing niobium content to the increase in APB energy.

At this point, one can now begin to speculate what might be the role of niobium in the alloys of this study. Niobium's moderate melting point and low modulus seem to indicate little potential for solid solution strengthening. Niobium's large atomic radius limits solubility in nickel alloys and its electropositive nature suggest a bias towards formation of stable carbides and nitrides. Its low density is a potential plus for a superalloy, particularly, if the alloy is to be used for a rotating part. Niobium's greatest potential lies in its ability to promote formation of $\gamma^{\prime}$ and $\gamma^{\prime}$. It tends to segregate to these two phases thus increasing their volume faction, while reducing the solubility of aluminum and titanium in the matrix, thereby further increasing the $\gamma$ and $\gamma^{\prime \prime}$ contents. Additionally, niobium is known to increase the APB energy of $\gamma^{\prime}$ thus increasing high temperature strength through enhancement of increasing resistance to dislocation cutting. 


\section{The Role of Niobium in Nickel-Iron Base Superalloys}

A significant number of wrought superalloys strengthened with niobium are technically nickel-iron base alloys. Included in this grouping are such well known alloys as 706, 718, 903, 907, 908 and 909. Two of these alloys (alloys 706 and 718) have been selected for characterization. Their composition is given in Table I. These alloys have several features in common:

- These alloys are mainly used forged or wrought in applications up to temperatures not to exceed $\sim 650^{\circ} \mathrm{C}$.

- These alloys employ niobium for strengthening, frequently as the primary means of enhancing performance through precipitation of coherent $\gamma^{\prime}$ and $\gamma^{\prime \prime}$ phases.

- The amount of nickel must exceed $25 \%$ to ensure a face-centered cubic (FCC) austenitic matrix in which $\gamma$ phase can precipitate.

\section{Solid Solution Strengthening in Nickel-Iron Base Superalloys}

As with the nickel-base superalloys, elements such as cobalt, chromium, molybdenum and tungsten along with niobium can lead to solid solution strengthening, although for niobium, precipitate phases play a more significant role. Stoloff estimated the level of niobium in solid solution in alloy 718 as $\sim 3.0 \%$ (8). This would suggest that the contribution to strengthening in nickel-iron base superalloys is about the same as in the experimental nickel-base superalloys discussed above. Given that the mismatch between $\gamma$ and $\gamma^{\prime}$ is not an important strengthening factor in nickel-base alloys, solid solution strengthening is not likely to be a major contributor to strength in nickel-iron base superalloys.

\section{Carbide Strengthening by Niobium in Nickel-Iron Base Superalloys}

The nickel-iron base superalloys form MC-type carbides. These carbides are important in controlling grain refinement during forging and heat treatment of this class of superalloys used widely as gas turbine discs and spacers. This carbide is generally titanium rich and generally complexed with niobium and the other refractory elements. Niobium helps stabilize the MC type carbide but it still can transform to $\mathrm{M}_{23} \mathrm{C}_{6}$ and $\mathrm{M}_{6} \mathrm{C}$ type carbides upon subsequent high temperature heat treatment or thermal exposure.

\section{Coherent Phase Strengthening by Niobium in Nickel-Iron Base Superalloys}

There are two coherent phases, $\gamma^{\prime}$ and $\gamma^{\prime \prime}$, that form in nickel-iron base superalloys. The first of these phases, $\gamma^{\prime}$, is an ordered and coherent phase, formed by reaction of titanium with nickel. This is in contrast to the formation of $\gamma^{\prime}$ in nickel-base alloys by the reaction of nickel with aluminum. However, aluminum does participate, if present, along with titanium in forming $\gamma^{\prime}$ in the nickel-iron matrix. Gamma prime particles in a nickel-iron matrix are usually spherical and their volume fraction and size are critical in determining their contribution to strengthening. Paulonis has estimated the APB energy contribution to coherency strain is approximately 10 to $20 \%$ thereby discounting coherency strain as a important contributor to strength in these alloys (9). Gamma prime $\left(\gamma^{\prime}\right)$ in the nickel-iron superalloy group of alloys can transform to $\gamma^{\prime \prime}$ as described below. 
Because of the presence of niobium in nickel-iron base superalloys, gamma double prime, $\gamma^{\prime \prime}$, can be a prime contributor to strength. This coherent phase is body-centeredtetragonal (BCT) (it can be equated to two stacked FCC $\gamma$ cells in structure). It forms as discs or platelets within the matrix, has been observed to envelop $\gamma$ particles, and is apparently more stable than $\gamma$. The phase depends on the presence of both niobium and iron, which provide the necessary electron-to-atom ratios and matrix to precipitate mismatch needed to form $\gamma^{\prime \prime}$. Figure 3 shows the quaternary phase relationships between $\gamma, \gamma, \gamma^{\prime \prime}$ and neighboring phases in the nickel, aluminum, niobium and chromium quaternary system.

While $\gamma^{\prime \prime}$ is more stable than $\gamma^{\prime}$, it in turn can transform to orthorhombic delta phase, $\delta$ $\left(\mathrm{Ni}_{3} \mathrm{Nb}\right)$, depending on alloy composition and thermal exposure. The phase transformation sequence is as follows:

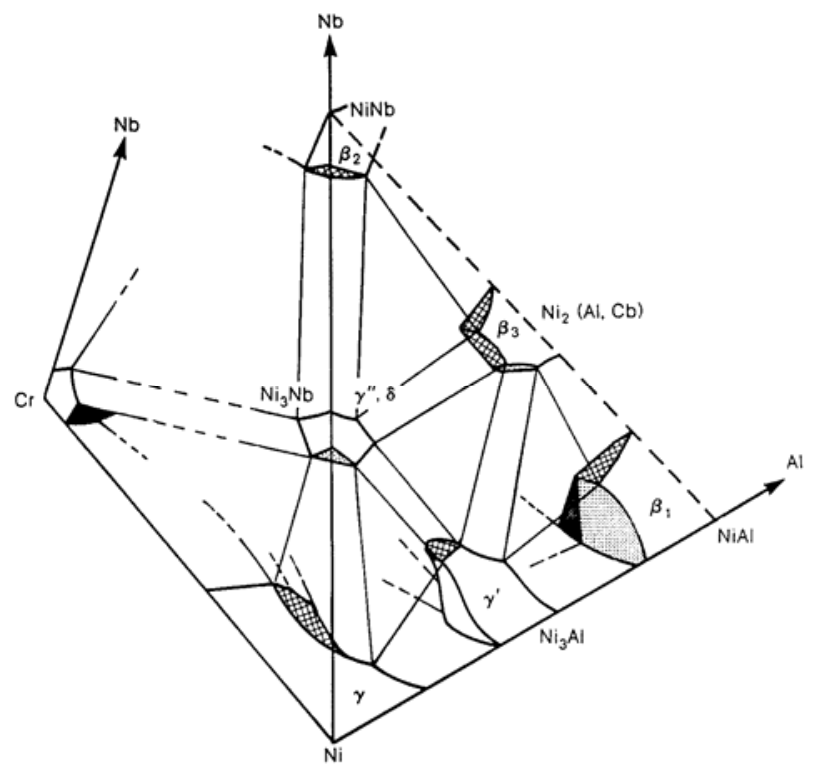

Figure 3: Sketch of the Approximate Relationships between $\gamma, \gamma, \gamma^{\prime}$ and $\delta$ in the NickelAluminum-Chromium-Niobium System.

$$
\gamma^{\prime}(\mathrm{FCC}) \rightarrow \gamma^{\prime \prime}(\mathrm{BCT}) \rightarrow \delta(\text { Orthorhombic) }
$$

Delta phase is non-coherent with the matrix and forms as plates or cells. While it can contribute to grain control, its contribution to strength is doubtful (10). Another phase that can form directly from $\gamma$ is eta phase, $\eta\left(\mathrm{Ni}_{3} \mathrm{Ti}\right)$, due to high levels of titanium and niobium in the alloy. Eta phase usually occurs as plates or cells and is frequently found in grain boundaries where it dramatically reduces ductility. Certain heat treatments can lead to a more benign blocky form of the phase that can be used like $\delta$ to control grain size during fabrication. The formation of $\eta$ and $\delta$ reduce potential strength since they both tie up titanium and niobium diminishing their availability to form $\gamma^{\prime}$ and $\gamma^{\prime \prime}$.

Nickel-iron base superalloys can also form topographically closed-packed (TCP) phases and Laves. The presence of Laves is not uncommon and is related to the presence of niobium, iron and silicon in the alloy. While not related to the niobium content of these superalloys the formation of sigma, $\sigma(\mathrm{Ni}, \mathrm{FeCr})$ can occur in highly segregated microstructures or if the matrix is sufficiently deprived of nickel due to the formation of $\gamma^{\prime}, \gamma^{\prime \prime}, \delta$ or $\eta$ phases. The most 
important niobium-containing phases that exist in nickel-iron base superalloys are summarized in Table IV.

With this cursory level of understanding of the characteristics of niobium, one can now begin to examine the role of niobium in the alloys selected for this paper. The nominal composition of these alloys is presented in Table $\mathrm{V}$ arranged in order of increasing niobium.

\section{Table IV. Superalloy Phases Containing Niobium}

\begin{tabular}{|c|c|c|c|}
\hline Name & Symbol & Structure & Chemical Formula \\
\hline Gamma & $\gamma$ & FCC & Solid Solution \\
\hline Gamma Prime & $\gamma^{\prime}$ & Ordered FCC & $\mathrm{Ni}_{3}(\mathrm{Al}, \mathrm{Ti}, \mathrm{Nb})$ \\
\hline Gamma Double Prime & $\gamma^{\prime}$ & Ordered BCT & $\mathrm{Ni}_{3}(\mathrm{Nb}, \mathrm{Al}, \mathrm{Ti})$ \\
\hline Delta & $\delta$ & Orthorhombic & $\mathrm{Ni}_{3}\left(\mathrm{Nb}_{8} \mathrm{Ti}_{2}\right)$ \\
\hline Eta & $\eta$ & $\mathrm{HCP}$ & $\mathrm{Ni}_{3}(\mathrm{Ti}, \mathrm{Nb})$ \\
\hline MC Carbide & $\mathrm{MC}$ & Cubic & $\mathrm{NbC}$ \\
\hline $\mathrm{M}_{6} \mathrm{C}$ Carbide & $\mathrm{M}_{6} \mathrm{C}$ & Complex Cubic & $(\mathrm{Nb}, \mathrm{Mo}, \mathrm{Ni})_{6} \mathrm{C}$ \\
\hline Laves & --- & Hexagonal MgZn & $(\mathrm{Fe}, \mathrm{Cr})_{2}(\mathrm{Ti}, \mathrm{Nb})$ \\
\hline
\end{tabular}

Table V. Nominal Composition of the Alloys of this Paper.

\begin{tabular}{|c|c|c|c|c|c|c|c|c|c|}
\hline Alloy & $\mathrm{Ni}$ & $\mathrm{Fe}$ & $\mathrm{Cr}$ & $\mathrm{Mo}$ & $\mathrm{Al}$ & $\mathrm{Ti}$ & $\mathrm{Nb}$ & $\mathrm{Si}$ & $\mathrm{C}$ \\
\hline $\mathrm{X}-750$ & 72.0 & 7.6 & 15.4 & -- & 0.9 & 2.5 & 0.9 & 0.1 & 0.04 \\
\hline 740 & 68.6 & 0.7 & 25.0 & 0.5 & 0.9 & 1.8 & 2.0 & 0.5 & 0.03 \\
\hline 706 & 41.6 & 36.8 & 16.1 & --- & 0.2 & 1.7 & 3.1 & -- & 0.02 \\
\hline 725 & 58.0 & 7.5 & 20.8 & 8.1 & 0.3 & 1.5 & 3.5 & -- & 0.01 \\
\hline 718 & 52.5 & 18.8 & 19.0 & 3.0 & 0.5 & 0.9 & 5.3 & --- & 0.04 \\
\hline
\end{tabular}

\section{Metallurgical Behavior of Niobium in Alloy X-750}

Alloy X-750 was developed by the Huntington Alloy Products Division of the International Nickel Company in the late 1930s. The alloy was based on the additions of aluminum $(0.9 \%)$, titanium $(2.5 \%)$ and niobium $(0.9 \%)$ to alloy 600 in order to obtain $\gamma^{\prime}(11)$. The nominal composition is given in Table $\mathrm{V}$. The alloy rapidly became employed in a number of gas turbine components including blading, discs and bolting. It was used for airframe applications, such as hot air ducting and thrust reversers as well as a number of industrial uses including heat-treating fixtures, forming tools, extrusion dies and test machine grips. The alloy possesses usable high strength to about $700^{\circ} \mathrm{C}$ above which much of the precipitation-hardening is lost. Optimum strength properties are achieved by solution treating at $1150^{\circ} \mathrm{C}$ plus stabilization at $850^{\circ} \mathrm{C}$ and precipitation hardening heat treatment at $700^{\circ} \mathrm{C}$. Over time and depending on product form and application a number of additional heat treatments were developed (12).

The time-temperature-transformation (TTT) diagram for the alloy was developed by A. A. Hesse in the late 1970s and is presented in Figure 4 (13). Included in this study was a determination of the precipitated phases found during the course of the development of the TTT diagram. These phases are listed in Table VI. 
A. A. Hesse reported the MC carbides existed both in the grain boundaries and in the matrix. The $\mathrm{M}_{23} \mathrm{C}_{6}$ was only present in the grain boundaries. Electrolytic extractions indicated the maximum amount of precipitated carbides to be 0.2 to 0.3 weight percent and the amount of $\gamma^{\prime}$ to be about 14 weight percent. The $\eta$ phase occurs as thin plates, generally intraganularly.

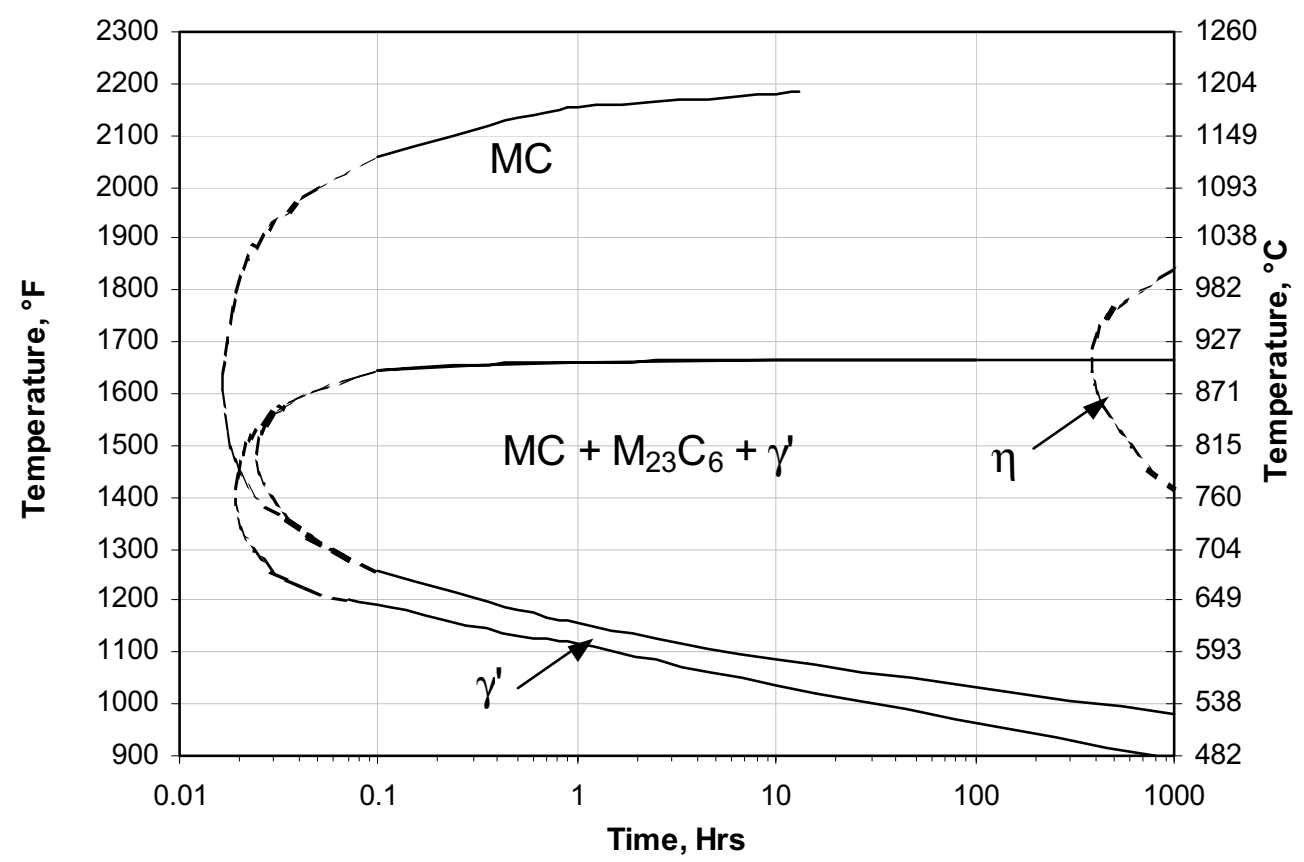

Figure 4. Time-Temperature-Transformation Diagram for Alloy X-750(12).

Table VI. Phases Present in Solution Annealed and Aged Alloy X-750

\begin{tabular}{|c|c|c|}
\hline Phase & Lattice Parameters $\left(\mathrm{A}_{\mathrm{o}}\right)$ & Composition \\
\hline Matrix & $3.57 \AA$ & $71 \mathrm{Ni}, 16 \mathrm{Cr}, 8 \mathrm{Fe}, 2 \mathrm{Ti}, 1 \mathrm{Nb}$ \\
\hline $\mathrm{MC}$ & $3.59 \AA$ & $\mathrm{Nb}$ rich, some $\mathrm{Ti}$ \\
& $4.35 \AA$ & Ti rich, some $\mathrm{Nb}$ \\
\hline $\mathrm{TiN}$ & $4.24 \AA$ & Ti rich, some Nb \\
\hline$\gamma^{\prime}$ & $3.59 \AA$ & $\mathrm{Ni}_{3}\left(\mathrm{Al}_{.5} \mathrm{Ti}_{.5}\right)$ \\
\hline $\mathrm{M}_{23} \mathrm{C}_{6}$ & $10.62 \AA$ & $\mathrm{Cr} \mathrm{rich} \AA$ \\
\hline$\gamma^{\prime}$ & $10.62 \AA$ & $\mathrm{Ni}_{3}\left(\mathrm{Ti}_{.6} \mathrm{Al}_{.25} \mathrm{Nb}_{.15}\right)$ \\
\hline
\end{tabular}

Hesse reports that when the Ti/Al ratio exceeds 4 that the $\eta$ phase forms more readily. It would appear that the majority of the niobium is initially contained in the matrix with a lesser amounts present in the $\mathrm{MC}$, TiN and $\eta$. Over time, the niobium appears to augment the aluminum in the $\gamma^{\prime}$ as the $\gamma^{\prime}$ transforms to $\eta$. E. L. Raymond has defined a significant role for niobium in the metallurgical behavior of the $\mathrm{M}_{23} \mathrm{C}_{6}$ as a function of time at elevated temperture (14).

The partitioning of the niobium to the carbides in alloy $\mathrm{X}-750$ has been studied by $\mathrm{E}$. L. Raymond. This author finds that the element in greatest abundance in the $\mathrm{M}_{23} \mathrm{C}_{6}$ that forms between $650^{\circ} \mathrm{C}$ and $820^{\circ} \mathrm{C}$ is niobium followed by titanium and finally by chromium. The level of niobium is initially in the 60 to $70 \%$ range and gradually decreases as chromium displaces both niobium and titanium in the carbide. At temperatures above $\sim 820^{\circ} \mathrm{C}$, the $\mathrm{MC}$ carbide is 
devoid of chromium and consists of $30 \%$ titanium, $70 \%$ niobium and $0.18 \% \mathrm{C}$. This establishes a role for niobium in aiding stabilization of the alloy against sensitization given a proper heat treatment. For alloy X-750, a heat treatment between $820^{\circ} \mathrm{C}$ and $930^{\circ} \mathrm{C}$ assures that the zone immediately adjacent to the carbide lamellae retains its chromium content, thereby inhibiting the solution of $\gamma^{\prime}$. This action eliminates a zone of lower strength along the grain boundaries that could potentially lower rupture life and favor crack growth.

\section{Metallurgical Behavior of Niobium in Alloy 740}

Alloy 740 is a recent development of Special Metals Corporation to meet the challenges created by the utility industry's move towards ultra-supercritical boiler operating conditions. To operate at steam temperatures of $700^{\circ} \mathrm{C}$ and above and at steam pressures of 325 bar or greater, requires a nickel-base alloy with precipitation-hardening characteristics coupled with resistant to the high sulfur atmospheres associated with burning coal. The composition of the alloy developed for this service is given in Table V. The alloy contains $2 \%$ niobium. It is the distribution and role of this element that is the focus of our interest in this study.

Several extensive investigations of the microstructural stability of INCONEL alloy 740 have been undertaken $(15,16)$. Dr. Xie and his colleagues at the U. of Beijing have reported on the precipitates found in the alloy after aging for times to 4,000 hours at $704^{\circ} \mathrm{C}\left(1300^{\circ} \mathrm{F}\right), 725^{\circ} \mathrm{C}$ $\left(1337^{\circ} \mathrm{F}\right)$ and $760^{\circ} \mathrm{C}\left(1400^{\circ} \mathrm{F}\right)(15)$. Evans, et. al., studied the microstructure of the alloy after creep testing solution annealed and aged material for 2,500 hours at $816^{\circ} \mathrm{C}\left(1500^{\circ} \mathrm{F}\right)$ and 138 $\mathrm{MPa}(20 \mathrm{ksi})$ (16). Both investigations reported the precipitates as $\gamma, \eta, \mathrm{M}_{23} \mathrm{C}_{6}$, G-phase and MC. It is worthwhile reporting the composition of these phases and that of the $\gamma$ matrix, as determined by Evans, et al., and presented in Table VII. This information is likely to be helpful in future efforts to enhance stability at $760^{\circ} \mathrm{C}\left(1400^{\circ} \mathrm{F}\right)$ and above.

Table VII. Measured Composition (atom \%) of the Phases Present After Creep Testing of INCONEL alloy 740 at $815^{\circ} \mathrm{C}\left(1500^{\circ} \mathrm{F}\right) / 138 \mathrm{MPa}(20 \mathrm{ksi})$ for 2,500 hours $(10)$.

\begin{tabular}{|c|c|c|c|c|c|c|c|c|c|}
\hline Phase & $\mathrm{Ni}$ & $\mathrm{Cr}$ & $\mathrm{Co}$ & $\mathrm{Fe}$ & $\mathrm{Ti}$ & $\mathrm{Al}$ & $\mathrm{Nb}$ & $\mathrm{Mo}$ & $\mathrm{Si}$ \\
\hline$\gamma$ & 44.6 & 32.7 & 21.2 & 0.5 & 0.3 & 0.1 & 0.2 & 0.1 & 0.3 \\
\hline$\gamma^{\prime}$ & 73.3 & 1.6 & 6.2 & 0.3 & 10.0 & 6.1 & 2.4 & 0 & 0 \\
\hline$\eta$ & 71.0 & 1.3 & 8.9 & 0.1 & 10.4 & 2.3 & 6.0 & 0 & 0 \\
\hline $\mathrm{M}_{23} \mathrm{C}_{6}$ & 3.5 & 93.5 & 1.6 & 0 & 0.1 & 0 & 0 & 1.2 & 0 \\
\hline $\mathrm{MC}$ & 1.2 & 0.9 & 0.6 & 0 & 32.0 & 0.1 & 64.5 & 0.2 & 0.5 \\
\hline $\mathrm{G}$ & 47.3 & 2.1 & 10.1 & 0.1 & 2.8 & 0.1 & 15.3 & 0 & 21.9 \\
\hline
\end{tabular}

These authors reported that the $\gamma^{\prime}$ coarsened from 60 to $250 \mathrm{~nm}$ in diameter during aging at $760^{\circ} \mathrm{C}$ in 4,000 hours and lost coherency with the $\gamma$ matrix, but did provide matrix strengthening via dislocation pinning. The grain boundary precipitates in their study were $\eta$, $\mathrm{M}_{23} \mathrm{C}_{6}$ and $\mathrm{G}$-phase. Laves and sigma phase were not found.

Xie, et al., examined the microstructure of solution annealed INCONEL alloy 740 bar after aging at $704^{\circ} \mathrm{C}\left(1300^{\circ} \mathrm{F}\right)$ and $725^{\circ} \mathrm{C}\left(1337^{\circ} \mathrm{F}\right)$ for $500,1,000,1,500$ and 2,000 hours (14). Very fine $\gamma^{\prime}$ precipitates (16.6\% after 2,000 hours) are distributed throughout the grains, which contribute the main strengthening effect. Larger $(\mathrm{Nb}, \mathrm{Ti}) \mathrm{C}$ particles $(0.15 \%$ after 2,000 hours $)$ are also observed throughout the grains, while the grain boundary precipitate after long term aging at $704^{\circ} \mathrm{C}\left(1300^{\circ} \mathrm{F}\right)$ is $\mathrm{Cr}_{23} \mathrm{C}_{6}(0.15 \%$ after 2,000 hours $)$. After aging at $725^{\circ} \mathrm{C}\left(1337^{\circ} \mathrm{F}\right)$ for 
4,000 hours, a small amount of needle-like $(\eta)$ and blocky precipitates (G-phase) have also formed in the grain boundaries. Gamma prime increases with time and temperature in the temperature range studied. At the initial stage of aging, the $\gamma^{\prime}$ particles were small and spherical and eventually became cuboidal with time and temperature, confirming the work of Evans, et al (15). The relationship between the radius of $\gamma^{\prime}$ and time is linear and follows the kinetics of diffusion controlled particle growth (15).

\section{Metallurgical Behavior of Niobium in Alloy 725}

Alloy 725 is a highly corrosion resistant nickel-based alloy that can be age-hardened to strength levels comparable to alloys 706 and 718 by the precipitation of $\gamma^{\prime}$ and $\gamma^{\prime}$ '(17). The nominal composition of this alloy is given in Table $\mathrm{V}$. This combination of high strength, ductility, and excellent corrosion resistance makes this alloy attractive for challenging applications in sea water, deep sour gas wells and mineral acids (18).

Mannan and Veltry published thermal stability data and a TTT diagram for alloy 725 (19). The TTT diagram is presented in this conference in the paper, "Alloys 625 and 725: Trends in Properties and Applications". Minor amounts of the primary carbide, (NbTi)C, and the nitride, TiN, can be found in the alloy. The principal strengthening phases for optimum strength are a combination of $\gamma^{\prime}$ and $\gamma^{\prime}$ ' achieved by aging at $730^{\circ} \mathrm{C} / 8 \mathrm{~h} /$ furnace cool at $56^{\circ} \mathrm{C} / \mathrm{h}$ to $620^{\circ} \mathrm{C} / 8 \mathrm{~h} /$ air cool. Solution annealing at $1040^{\circ} \mathrm{C}$ with a rapid quench prior to aging avoids the possibility of $\eta$ formation since the solvus range for the phase is estimated to be between $980^{\circ}$ and $1040^{\circ} \mathrm{C}$. The principal location of the niobium is expected to reside in the $\gamma^{\prime}$.

\section{Metallurgical Behavior of Niobium in Alloy 706}

Alloy 706 evolved from the development of alloy 718 in the late 1960s to satisfy metallurgical requirements for large forged gas turbine components (20). Nickel, molybdenum and hardener content were lowered to enhance forgeability, reduce the tendency of the alloy range to develop macrosegregation in large cross sections, improve machinability and lower cost. Niobium and aluminum content were also reduced to decrease the tendency for segregation and freckle formation. The reduction of these hardeners necessitated an increase in the titanium content to maintain the alloy's strength characteristics. The carbon content was lowered from that in alloy 718 to aid machinability. The nominal composition of alloy 706 is shown in Table V. The major phases and their typical morphologies found in alloy 706 are described in Table VIII below.

$\underline{\text { Table VIII. Major Precipitating Phases Present in Alloy } 706}$

\begin{tabular}{|c|c|c|c|}
\hline Precipitating Phase & Structure & Morphology & Composition \\
\hline$\gamma^{\prime}$ & Ordered FCC & Spheres & $\mathrm{Ni}_{3}(\mathrm{Al}, \mathrm{Ti})$ \\
\hline$\gamma^{\prime \prime}$ & Ordered BCT & Disks & $\mathrm{Ni}_{3} \mathrm{Nb}$ \\
\hline Laves & HCP & Globular & $(\mathrm{Fe}, \mathrm{Ni})_{2} \mathrm{Nb}$ \\
\hline$\eta$ & HCP & Platelets/Cellular & $\mathrm{Ni}_{3} \mathrm{Ti}$ \\
\hline
\end{tabular}

Gamma prime $\gamma^{\prime}$ and $\gamma^{\prime}$ are present in alloy 706 along with MC carbides, Laves and $\eta$ phases (21). The principal strengthening phase is $\gamma^{\prime}$. Heck has developed a TTT diagram for the alloy (22). 
To establish guidelines for forging, the re-solution temperatures for the common phases present in alloy 706 have been established (23). Both $\gamma^{\prime}$ and $\gamma^{\prime \prime}$ re-solution at $\sim 885^{\circ} \mathrm{C}$ (slightly lower for longer times), phases $\eta$ and $\delta$ at $\sim 955^{\circ} \mathrm{C}$ (somewhat higher if the material is adversely segregated), grain boundary Laves at $\sim 1065^{\circ} \mathrm{C}$ or higher if the particles are large. Moll, Maniar and Muzyka have presented an excellent review of the behavior of these phases during processing and heat treatment (24). Numerous articles exist on the melting, processing and heat treatment of alloy and the interested reader is referred to these papers, since the focus here is on the role of niobium (25-29).

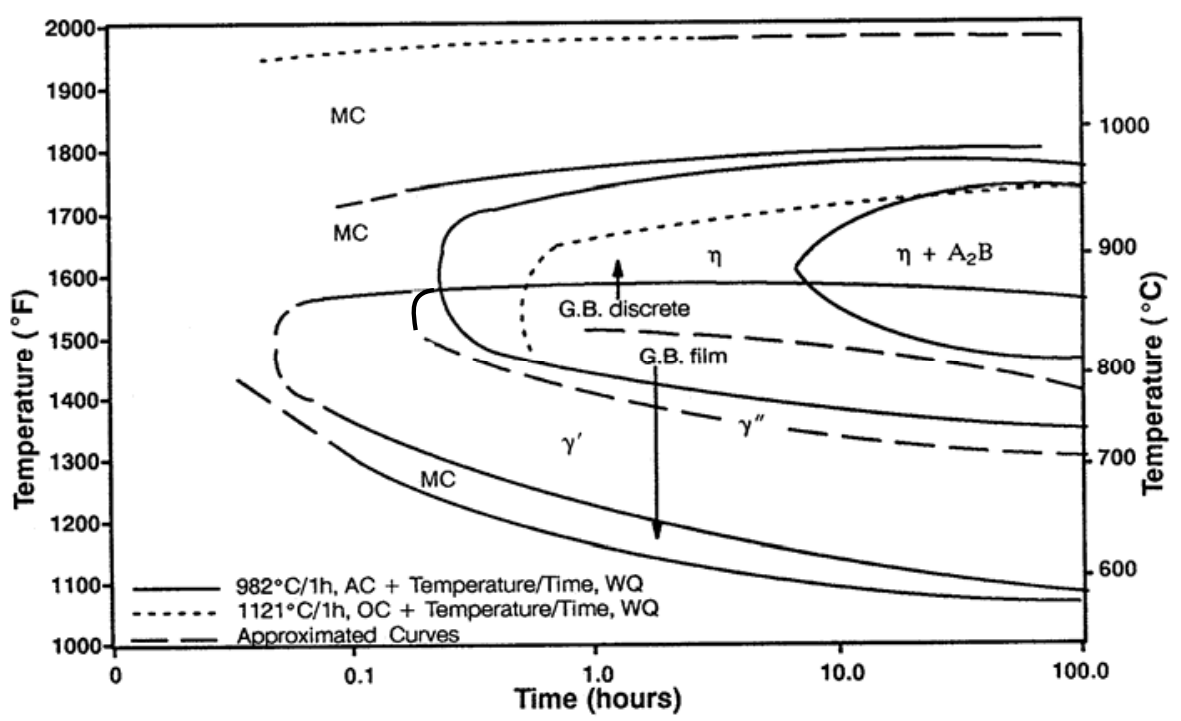

Figure 5: Time-Temperature-Transformation Diagram for Alloy 706 (23).

Gamma prime $\left(\gamma^{\prime}\right)$ is the principal age hardening phase formed by isothermal heat treatment at and below $\sim 700^{\circ} \mathrm{C}$ although it precipitates before $\gamma^{\prime \prime}$ at $760^{\circ} \mathrm{C}$. It is generally spherical in shape and is an ordered $\mathrm{L1}_{2}(\mathrm{a}=3.57$ Angstroms) crystal structure. Extended exposure above $\sim 650^{\circ} \mathrm{C}$ cause the $\gamma^{\prime}$ to transform to more stable $\eta$ phase, in the form of coarse platelets, either in cellular colonies growing from grain boundaries or as an intragranular Widmanstatten structure. This transformation lowers strength.

Gamma double prime $\left(\gamma^{\prime \prime}\right)$ is the predominate strengthening phase formed by heat treating between $\sim 700^{\circ} \mathrm{C}$ and $\sim 760^{\circ} \mathrm{C}$ although some $\gamma^{\prime \prime}$ will form over a broader temperature range. This phase is usually disc shaped and has an ordered BCT crystal structure. Gamma double prime $\left(\gamma^{\prime}\right)$ co-exists with the onset of titanium-rich $\eta$ precipitation and appears to transform to $\eta$ simultaneously with the appearance of $\gamma^{\prime}$ (21). Some investigators have reported the transformation of $\gamma^{\prime \prime}$ to coarse platelets of the stable orthorhombic $\left(\mathrm{DO}_{\mathrm{a}}\right) \delta$ phase with identical composition after long-term exposures above $\sim 650^{\circ} \mathrm{C}$. This phase can also form directly at higher temperatures (30).

The third precipitate of consequence in alloy 706 is eta phase, $\eta\left(\mathrm{Ni}_{3} \mathrm{Ti}, \mathrm{Nb}\right)$. This phase has a hexagonal $\mathrm{DO}_{24}$ crystal structure and appears as small platelets in grain boundaries and as thin lengthy platelets (needles) within the grains. It coarsens at the expense of $\gamma^{\prime}$ and $\gamma^{\prime \prime}$ between $\sim 760^{\circ} \mathrm{C}$ and $\sim 870^{\circ} \mathrm{C}$. It nucleates uniformly within grains after an $1120^{\circ} \mathrm{C}$ anneal, but nonuniformly from lower annealing temperatures. This may be due to a remnant substructure related to prior precipitation of $\mathrm{MC}$ type particles since carbide formation appears to influence the $\eta$ solvus temperature. There is compositional transition of $\gamma^{\prime \prime}\left(\mathrm{Ni}_{3} \mathrm{Nb}\right)$ [orthorhombic, $\mathrm{DO}_{22}$ ] 
to $\eta\left(\mathrm{Ni}_{3} \mathrm{Nb}_{0.33} \mathrm{Ti}_{0.67}\right)$ [hexagonal, $\mathrm{DO}_{24}$ ]. Eta phase can further transform with increasing titanium to $\eta\left(\mathrm{Ni}_{3} \mathrm{Nb}_{0.11} \mathrm{Ti}_{0.89}\right)$ [rhombohedral] to $\eta\left(\mathrm{Ni}_{3} \mathrm{Nb}_{0.03} \mathrm{Ti}_{0.97}\right)$ [hexagonal, $\mathrm{DO}_{24}$. Precipitation of $\eta$ to control grain size during forging is a common practice $(23,27,31)$. Experience has shown that working alloy 706 below the $\eta$ solvus temperature $\left(\sim 954^{\circ} \mathrm{C}\right)$ significantly increases flow stress and consequently forge press requirements. As recently as November, 2000, Balbach et al. patented a stabilizing step in the aging of alloy 706 for enhanced resistance to crack growth by heat treating at 775 to $835^{\circ} \mathrm{C}$ for 5 to $100 \mathrm{~h}$ after a 965 to $995^{\circ} \mathrm{C} / 5$ $20 \mathrm{~h}$ solution anneal prior to the usual precipitation aging steps (32). The result of this stabilization heat treatment is the formation of substantial amounts of agglomerated $\eta$ phase in the grain boundaries responsible for the inhibition of crack growth.

Alloy 706 will form Laves phase $\left(\mathrm{Fe}_{2} \mathrm{Nb}\right)$ [hexagonal, $\mathrm{C} 36$ crystal structure] after extended exposure in the temperature range of about 870 to $930^{\circ} \mathrm{C}$. Laves tends to look microstructurally like grain boundary $\eta$ although somewhat coarser. Fesland and Petit studied the effect of silicon content on Laves phase formation in alloy 706 and presented the TTT diagram shown in Figure 8 for an alloy containing from 0.04 to $0.25 \%$ silicon (33). Kuhlman et al. confirmed the observations of Fesland and Petit in their study of the microstructuremechanical property relationships in alloy 706 containing $0.07 \%$ silicon (34).

Niobium and titanium rich $\mathrm{MC}$ carbide $\left(\mathrm{FCC}, \mathrm{A}_{\mathrm{o}}=4.43\right)$ form in alloy 706 as a very fine precipitates mainly on grain boundaries during processing and aging heat treatments. Small amounts of $\mathrm{M}_{23} \mathrm{C}_{6}, \mathrm{M}_{3} \mathrm{C}, \mathrm{NbN}$ or $\mathrm{Nb}(\mathrm{C}, \mathrm{N})$ type phases may occasionally be microstructurally observed.

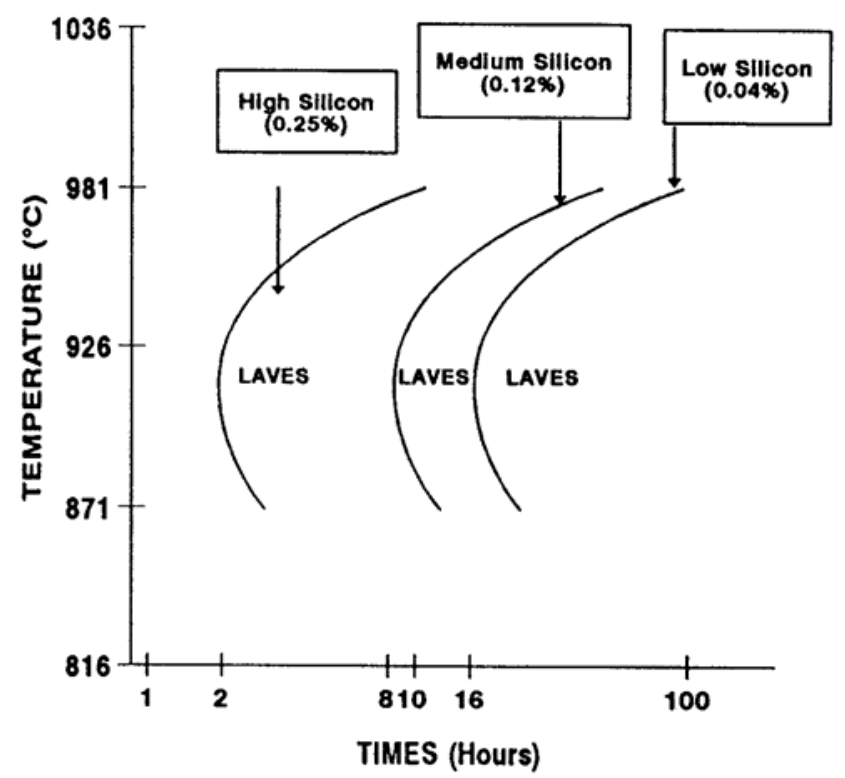

Figure 6: Time-Temperature-Transformation Diagram Showing the Effect of Silicon Content on the Formation of Laves Phase in Alloy 706 (33).

Optimum strength in alloy 706 is provided when a fine dispersion of $\gamma^{\prime \prime} \gamma^{\prime}$ is formed in the alloy and subsequently stabilized. A common practice is $718^{\circ} \mathrm{C} / 8 \mathrm{~h} / \mathrm{AC}$, furnace cool at $55^{\circ} \mathrm{C} / \mathrm{h}$ to $621^{\circ} \mathrm{C} / 8 \mathrm{~h}$ and then air cool. This procedure achieves excellent strength properties in less time with less likelihood of overaging to intragranular $\eta$ than if a longer time isothermal heat treatment were used. Where maximum stress rupture strength is needed a third step of $843^{\circ} \mathrm{C} / 3 \mathrm{~h}$ is inserted between the anneal (optimally between 982 and $1010^{\circ} \mathrm{C}$ to avoid $\eta$ and Laves phase 
formation) and the first aging step. This step, near the $\gamma^{\prime \prime} / \gamma^{\prime}$ solvus, precipitates discontinuous grain boundary $\eta$ that improves notch ductility.

\section{Metallurgical Behavior of Niobium in Alloy 718}

Alloy 718 is the predominant nickel-iron base superalloy. It represents almost half of the total tonnage of superalloy used throughout the world. The composition is shown in Table V and the niobium-containing phases potentially present in the alloy are defined in Table IX. It is made in virtually all product forms and is used for forged disks, shafts, supports, fasteners, sheet components and frame sections (35). The 53\% nickel-19\% iron matrix is strengthened mainly by $5.3 \%$ niobium that forms $\gamma^{\prime \prime}(\sim 18$ to $20 \%)$ giving alloy 718 a higher yield strength than other superalloys strengthened by an equivalent amount of $\gamma^{\prime}$. However, $\gamma^{\prime \prime}$, being metastable, can transform to $\delta$ after long periods at temperatures at and above $\sim 650^{\circ} \mathrm{C}$ resulting in some loss of strength (36-41).

Table IX. Niobium-Containing Phases in Alloy 718 [Wlodek and Field (37)]

\begin{tabular}{|c|c|c|c|c|c|c|c|c|}
\hline \multirow{2}{*}{ Phase } & \multirow{2}{*}{ Structure } & \multicolumn{7}{|c|}{ Analysis, at. \% } \\
\cline { 3 - 9 } & $\mathrm{Nb}$ & $\mathrm{Al}$ & $\mathrm{Ti}$ & $\mathrm{Fe}$ & $\mathrm{Cr}$ & $\mathrm{Mo}$ & $\mathrm{Si}$ \\
\hline$\gamma$ & $\mathrm{A} 1$ & 1.97 & 0.74 & 0.52 & 23.8 & 22.0 & 2.41 & 0.64 \\
\hline$\gamma^{\prime}$ & $\mathrm{L} 12$ & 10.2 & 8.00 & 9.40 & 2.15 & 0.50 & 0.490 & 0.35 \\
\hline$\gamma^{\prime \prime}$ & $\mathrm{DO} 2$ & 25.1 & 0.44 & 4.92 & 0.86 & 0.76 & 1.05 & 0.01 \\
\hline$\delta$ & $\mathrm{DOa}$ & 20.4 & 0.80 & 3.00 & 5.30 & 3.40 & 2.20 & 0.10 \\
\hline Laves & $\mathrm{C} 14$ & 18.8 & 0.10 & 0.60 & 15.0 & 15.3 & 10.2 & 4.50 \\
\hline MC $^{*}$ & $\mathrm{~B} 1$ & 14.6 & 0.10 & 80.0 & 0.90 & 1.90 & 0.50 & 1.90 \\
\hline
\end{tabular}

* May contain nitrogen, also a high niobium form has been identified with 84 at.\% $\mathrm{Nb}, 7$ at. $\% \mathrm{Ti}$ and small amounts of $\mathrm{Fe}, \mathrm{Ni}$ and $\mathrm{Cr}$.

Like alloy 706, alloy 718 precipitates $\gamma^{\prime \prime}$ as fine coherent platelets in the $\gamma$ matrix. It is possible for the $\gamma^{\prime \prime}$ to surround cubic $\gamma^{\prime}$ on all its six faces under certain thermal conditions and specific ratios of $(\mathrm{Al}+\mathrm{Ti}) / \mathrm{Nb}(42)$. This morphology has been proven to retard coarsening. Rizzo and Buzzanell have shown that increasing amounts of niobium from 3.5 to $6.5 \%$ steadily increase strength (43). However, above $\sim 5 \%$, niobium promotes Laves and $\delta$ that in alloy 718 are potentially deleterious to both toughness and strength. The composition of Laves phase can typically ties up $19 \%$ of the niobium and $10 \%$ of the molybdenum contained in alloy 718 preventing these alloying elements to contribute to strength. Homogenization of castings to eliminate Laves is difficult by heat treatment only. One technique to enhance homogenization and eliminate Laves has been described by Bouse and Schilke (44). They used a combination hot isostatic pressing (HIP) cycle plus heat treatment to minimize freckling and improve the yield strength from 780 to $920 \mathrm{MPa}$ while retaining good ductility.

Numerous TTT diagrams have been described for alloy 718 , one such diagram is shown in Figure 7 for wrought alloy 718 containing 5.38\% niobium and $0.07 \%$ silicon (45). 


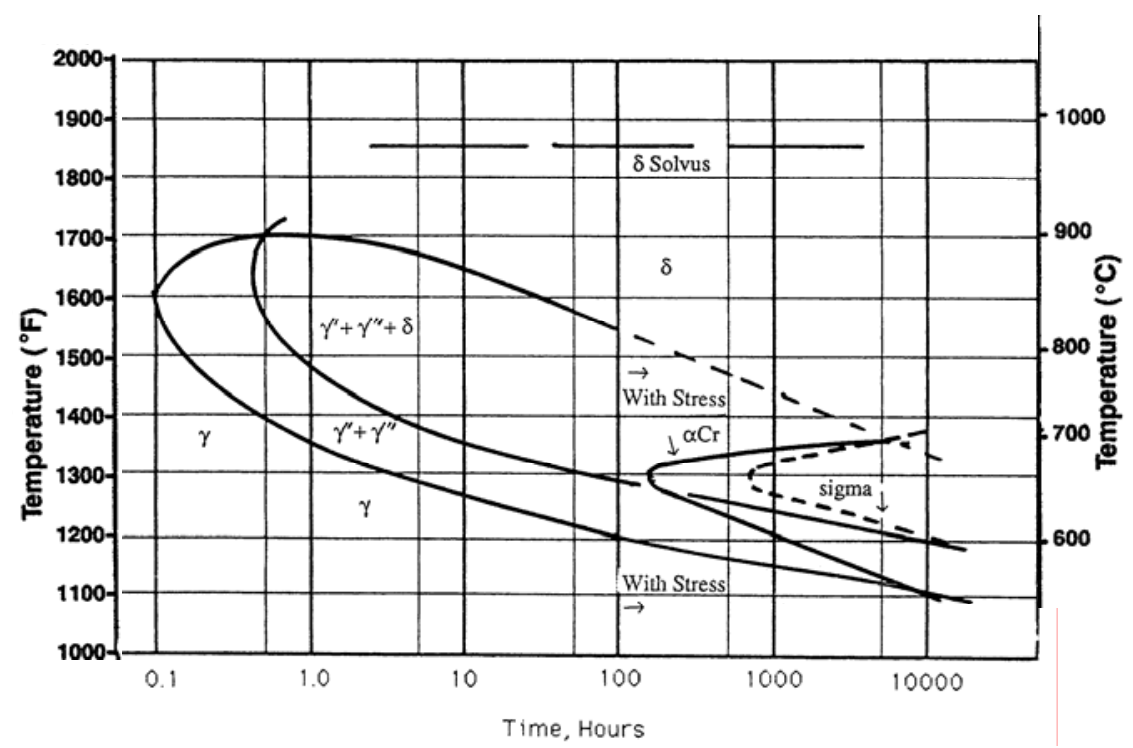

Figure 7. Time-Temperature-Transformation Diagram for Alloy 718 (45).

This diagram shows that in homogenized alloy 718 only $\gamma^{\prime}, \gamma^{\prime \prime}$ and $\delta$ are formed subsequent to hot working and an anneal at $1000^{\circ} \mathrm{C} / 15$ minutes. In this diagram, the primary carbides and any potential TiN are not depicted nor is Laves shown in confirmation of the results of Decker (46) and that of Brooks and Bridges (47). Interestingly, because the alloy contained $0.07 \%$ silicon, the primary $\mathrm{MC}$ carbides did not transform to $\mathrm{M}_{6} \mathrm{C}$ type carbides. The typical heat treatment requires an initial aging treatment at $720^{\circ} \mathrm{C} / 8 \mathrm{~h}$, furnace cool to $620^{\circ} \mathrm{C}$ and hold for total aging time of $18 \mathrm{~h}$ followed by an air cool. This heat treatment defines the typical microstructure of alloy 718 in service usually at a temperature not in excess of $650^{\circ} \mathrm{C}$. The $\gamma^{\prime \prime}$ forms readily at $720^{\circ} \mathrm{C}$. Once the $\gamma^{\prime \prime}$ is precipitated, the $\gamma^{\prime}$ can form in the areas between the $\gamma^{\prime \prime}$ particles since the lower niobium content favors $\gamma^{\prime}$ formation. The precipitation of $\alpha \mathrm{Cr}$ as first observed by Radavich after long term exposure or in shorter times under stress confirms the presence of these phases as reported by Wlodek and Field (37) and Brooks and Bridges (47).

Other diagrams such as those of Eiselstein (20) and Sims (4) depict the rapid formation of $(\mathrm{Nb}, \mathrm{Ti}) \mathrm{C}$ which over time transforms to $(\mathrm{Nb}, \mathrm{Ti})_{6} \mathrm{C}$. However, at typical use temperatures for alloy 718 , it would appear that these carbides are relatively unstable and may decompose. Low carbon $(0.008$ to $0.027 \%)$ heats of alloy 718 have been studied by Jackman, et al. They report that at $0.008 \%$ carbon, stringers and clusters are eliminated and while grain growth became a problem to resolve, the fatigue, impact and fracture toughness improved substantially (48). Further, eliminating or minimizing niobium-rich carbides, frees niobium for strength enhancing phases.

\section{$\underline{\text { Conclusions }}$}

The contribution of niobium to the performance of superalloys is significant and the result of many of its fundamental characteristics (4). These are summarized below as are the unique ways that niobium enhance the properties of superalloys. The niobium phases that form in alloys $725, \mathrm{X}-750,740,706$ and 718 are highlighted to define certain of their characteristics that these phases bring to precipitation-hardened wrought alloys. 
1. The melting point and low modulus suggest limited benefit of niobium as a solid solution strengthener. Its large atom size mismatch with that of nickel and iron suggests limited solubility potential.

2. Niobium's electropositive position in the periodic table predicts the formation of stable carbides and nitrides. Thermodynamic considerations suggest niobium may compete with scale forming elements for surface oxide formation.

3. Atom size and electropositive position favor solubility of niobium in the phases, $\gamma^{\prime}, \gamma^{\prime \prime}, \eta$ and $\delta$.

4. Niobium readily concentrates in the $\gamma^{\prime}$ phase thereby adding to the total volume fraction of this phase by as much as $30 \%$.

5. Niobium increases the APB energy of the $\gamma^{\prime}$ phase thereby increasing its resistance to dislocation cutting thus aiding high temperature strength.

6. The strong reaction of niobium with carbon to form $\mathrm{NbC}$ can be effectively utilized to control grain size, aid high temperature strength by reducing grain boundary slip and by preventing $\mathrm{MC}$ plus $\gamma$ phase degregation to $\mathrm{M}_{23} \mathrm{C}_{6}$ and $\gamma$ phase. In nickel alloys, up to 15$20 \%$ of the niobium presence partitions to the carbides.

7. In the presence of superalloys containing both nickel and iron, niobium forms $\gamma^{\prime \prime}$ phase leading to exceptional strength up to $\sim 650^{\circ} \mathrm{C}$. At higher temperatures over extended periods of time, $\gamma^{\prime \prime}$ phase will transform to $\delta$ phase, which does not contribute significantly to strength.

8. Eta $(\eta)$ phase in alloy 706 and delta $(\delta)$ phase in alloy 718 can be effectively utilized to control grain size during mill processing and is the basis of certain mini-grain processing schemes and products.

\section{References}

1. E. Guo and F. Ma, "The Strengthening Effect of Niobium in Ni-Cr-Ti Type Wrought Superalloy," Superalloys 1980, ed. J. K. Tien, ASM Press, Metals Park, OH, 1980, pp. 431438.

2. J. Mihalisin, C. G. Bieber and R. T. Grant, "Sigma-Its Occurrence, Effect and Control in Nickel-Base Superalloys," Trans. AIME, 242, 1968, pp.2399-2414.

3. H. J. Beattie and W. C. Hagel, "Intragranular Precipitation of Intermetallic Compounds in Complex Austenitic Alloys," Trans. AIME, 221, February 1967, pp. 28-35.

4. C. T. Sims, "A Perspective of Niobium in Superalloys," in Niobium-Proceedings of the International Symposium, ed. H. Stuart, TMS, 1981, pp. 1169-1220.

5. G. Harris and N. Child, "Development of a High-Temperature Alloy for Gas-Turbine Rotor Blades", in A Symposium on High Temperature Steels and Alloys for Gas Turbines, Iron and Steel Institute, London, July, 1952, pp. 67-80. 
6. O. Kriege and J. Baris, "The Chemical Partitioning of Elements in Gamma Prime Separated From Precipitation-Hardened, High-Temperature Nickel-Base Alloys", ASM Trans.Quarterly, March, 1969, 62, (1) pp. 195-200.

7. P. Thornton, et al., "The Temperature Dependence of the Flow Stress of the $\gamma$ Phase Based upon $\mathrm{Ni}_{3} \mathrm{Al}^{\prime}$, Met. Trans., 1, January, 1970, pp. 207-218.

8. N. Stoloff, "Fundamentals of Strengthening" The Superalloys, Wiley-Interscience, NYork, 1972, pp. 79-112.

9. D. Paulonis, et al., "Precipitation in Nickel-Base Alloy 718”, Met. Trans., 62, 1969, pp. 611622.

10. D. R. Muzyka and G. N. Maniar, "Microstructure Approach to Property Optimization in Wrought Superalloys,” ASTM STP 557, ASTM, Philadelphia, PA 1974, pp. 198-209.

11. F. B. Howard-White, Nickel-An Historical Review, VanNostrand, 1963.

12. INCONEL alloy X-750 Technical Bulletin, Special Metals Corporation, Oct., 2003.

13. A. A. Hesse, "Time-Temperature-Transformation Diagram for INCONEL alloy X-750", Internal Report of the Huntington Alloy Products Div. Of the International Nickel Co., 1979.

14. E. L. Raymond, "Mechanisms of Sensitization and Stabilization of INCOLOY alloy 825," (Paper presented at South Central Region NACE Conference, Denver, CO, Oct. 16-19, 1967).

15. S. Zhao, J. Dong, X. Xie, G. D. Smith and S. J. Patel, "Thermal Stability Study on a New NiCr-Co-Mo-Nb-Ti-Al Superalloy," Paper presented at $10^{\text {th }}$ International Symposium on Superalloys, Seven Springs, PA, September, 2004.

16. N. D. Evans, P. J. Maziasz, R. W. Swindeman, G. D. Smith, "Microstructure and Phase Stability in INCONEL alloy 740 during Creep,” Scripta Materialia, 51, 2004.

17. E. L. Hibner, H. W. Sizek and S. K. Mannan, "Elevated Temperature Tensile and Creep Properties of INCONEL alloy 725", Paper presented at Superalloys 718, 625, 706 and Various Derivatives, Ed. E. A. Loria, (Warrendale, PA: TMS, 1997), pp. 491-501.INCONEL alloy 725 Technical Bulletin, Publication \# SMC-066, Special Metals Corp., 2003.

18. S. K. Mannan, S. J. Patel, J. Dong and X. Xie, "Crack Growth and High Temperature Thermal Stability of INCONEL alloy 725", Intermetallics and Superalloys, EUROMAT 99, Vol. 10, Ed. D. G. Morris, S. Naka and P. Caron, Wiley-VCH, Weinheim, Germany, 2000, pp. 15-21.

19. S. K. Mannan and F. Veltry, "Time-Temperature-Transformation Diagram of Alloy 725", Paper presented at Superalloys 718, 625, 706 and Various Derivatives, Ed. E. A. Loria, (Warrendale, PA: TMS, 1997), pp. 491-501.

20. H. L. Eiselstein, "Properties of INCONEL alloy 706," Paper presented at Materials Engineering Congress, Cleveland, OH 1970. 
21. L. Remy, J. Laniesse and H. Aubert, "Precipitation Behavior and Creep Rupture of 706 Type Alloys, Materials Science and Engineering, 38, 1979, pp. 227-239

22. K. A. Heck, "The Time-Temperature-Transformation Behavior of Alloy 706," Paper presented at Superalloys 718, 625, 706 and Various Derivatives, ed. E. A. Loria, TMS, Warrendale, PA, 1994, pp. 393-404.

23. D. R. Muzyka and G. N. Maniar, "Microstructure Approach to Property Optimation in Wrought Superalloys", ASTM STP 557, ASTM, Philadelphia, PA, 1974, pp. 198-209.

24. J. H. Moll, G. N. Maniar and D. R. Muzyka, "The Microstructure of 706, A New Fe-NiBase Superalloy,” Metallurgical Transactions, 2, \#8, August, 1971, pp. 2143-2151.

25. P. W. Schilke, J. J. Pepe and R. C. Schwant, "Alloy 706 Metallurgy and Turbine Application," Paper presented at Superalloys 718, 625, 706 and Various Derivatives, ed. E. A. Loria, TMS, Warrendale, PA, 1994, pp. 1-12.

26. S. V. Thambo, "Melt Related Defects in Alloy 706 and Their Effects on Mechanical Properties," ibid., pp. 237-152.

27. C. P. Sullivan and M. J. Donachie, "Microstructures and Mechanical Properties of Iron-Base (Containing Ni) Superalloys,” Metals Engrg Quarterly, November, 1971, pp. 1-11.

28. A. M. Johnson and K. E. Fritz, "Properties and Microstructure of a Large Forged Superalloy Wheel", Superalloys - Metallurgy and Manufacture, Proceedings of $3^{\text {rd }}$ International Symposium, ed. B. H. Kear, et al., Published by Claitor's Publishing Division, Baton Rouge, LA, 1976, pp. 25-35.

29. F. S. Suarez, J. E. Roberts and L. D. Schley, "Ingot Optimization in a Superalloy INCONEL alloy 706," Presented at Fifth Int'1 Symposium on Electroslag and Other Special Melting Technologies, Carnegie-Mellon Institute of Research, Pittsburgh, PA, 1975, pp. 126149.

30. R. Cozar and A. Pineau, "Morphology of $\gamma^{\prime}$ and $\gamma^{\prime}$ Precipitates and Thermal Stability of INCONEL alloy 718 Type Alloys, Metall. Trans,. 4, 1973, pp. 47-59.

31. D. R. Muzyka, "Controlling Microstructures and Properties of Superalloys Via Use of Precipitated Phases,” Metals Engrg Quarterly, November 1971, pp. 12-19.

32. W. Balbach, G. Harkegard and R. Redecker, "Heat Treatment Process for Material Bodies Made of a High Temperature Resistant Iron-Nickel Superalloy and Heat Treatment Material Body,” U. S. Patent \#6,146,478, November 14, 2000.

33. J. P. Fesland and P. Petit, "Manufacturing Alloy 706 Forgings," Paper presented at Superalloys 718, 625, 706 and Various Derivatives, ed. E. A. Loria, TMS, Warrendale, PA, 1994, pp. 229-248.

34. G. W. Kuhlman, A. K. Chakrabarti, R. A. Beaumont, E. D. Seaton and R. F. Radavich, "Microstructure-Mechanical Properties Relationships in INCONEL alloy706 Superalloy," ibid., pp. 441-450. 
35. INCONEL alloy 718, Technical Bulletin, Special Metals Corporation, 2000.

36. A. Oradei-Basile, and J. F. Basile, "A Current T.T.T. Diagram for Wrought Alloy718," Paper presented at Superalloys 718, 625, 706 and Various Derivatives, ed. E. A. Loria, TMS, Warrendale, PA, 1991, pp. 325-335.

37. S. T. Wlodek and R. D. Field, "The Effects of Long Time Exposure on Alloy 718,",Paper presented at Superalloys 718, 625, 706 and Various Derivatives, ed. E. A. Loria, TMS, Warrendale, PA, 1994, pp. 659-670.

38. J. H. Davidson, "The Structural Stability of High Temperature Alloys," Paper presented at Course on The Structure of High Temperature Alloys, PETTEN Institute, The Netherlands.

39. C. I. Garcia, A. K. Lis, E. A. Loria and A. J. DeArdo, "Thermomechanical Processing and Continuous Cooling Transformation Behavior of Alloy 718," Superalloys 1992, ed. S. D. Antolovich, et al., TMS, Warrendale, PA, 1992, pp. 527-536.

40. R. Cozar, M. Rouby, B. Mayonobe, C. Morizot, "Mechanical Properties, Corrosion Resistance and Microstructure of Both Regular and Titanium Hardened 625 Alloys," Paper presented at Superalloys 718, 625 and Various Derivatives, ed. E. A. Loria, TMS, Warrendale, PA, 1991, pp. 423-436.

41. W. J. Boesch and H. B. Canada, "Precipitation Reactions and Stability of $\mathrm{Ni}_{3} \mathrm{Cb}$ in INCONEL alloy 718", Journal of Metals, 21, October, 1969, pp. 34-38.

42. T. Shibata, Y. Shudo, T. Takahashi, Y. Yoshino and T. Ishiguro, "Effect of Stabilizing Treatment on Precipitation Behavior of Alloy 706," Superalloys 1996, ed. R. D. Kissinger, et al., TMS, Warrendale, PA, 1996, pp. 627-634.

43. F. Rizzo and J. Buzzanell, "Effect of Chemistry Variations on the Structural Stability of Alloy 718", Journal of Metals, 21, 1969, pp. 24-33.

44. G. Bourse and P. Schilke, "Process Optimization of Cast Alloy 718 for Water Cooled Gas Turbine Application", Proc. Fourth Int'l Conference on Superalloys, ASM Press,Metals Park, OH, 1980, pp.303-310.

45. A. Oradei -Basile and J. F. Radavich, "A Current T-T-T Diagram for Wrought Alloy 718." Paper presented at Superalloys 718, 625 and Various Derivatives, ed. E. A. Loria, TMS, Warrendale, PA, 1991, pp. 325-336.

46. R. F. Decker, "Strengthening Mechanisms in Nickel-Base Superalloys," Paper presented at The Steel Strengthening Mechanisms Symposium, Zurich, Switzerland, 1969.

47. J. W. Brooks and P. J. Bridges, "Metallurgical Stability of INCONEL alloy 718," Paper presented at Superalloys 1988, ed. S. Reichman, et al., TMS, Warrendale, PA, 1988, pp.3342.

48. L. A. Jackman, M. D. Boldy and A. L. Coffey, “ The Influence of Reduced Carbon on Alloy 718," Paper presented at Superalloys 718, 625 and Various Derivatives, ed. E. A. Loria, TMS, Warrendale, PA, 1991, pp. 261-270. 